\title{
The Effect of A Detraining on some physical variables and body composition During the transition period for wrestlers
}

\section{"Dr/ Mosad Hassan Mohamed hedya}

ABSTRACT: The aim of this research is to identify the effect of the detraining on some physical variables and body composition during the transition period of wrestlers from 17-21 years to the same sample of 18 wrestling players from the Mansoura University students for different categories after the end of the training season for the academic year 2015-2016. search time (10) weeks, the researcher used the measurement (age, height, Weight, training age) and (maximum strength, Strength Endurance Explosive Strength Power, flexibility, Agility), and measurements of body composition (Weight, fat rate, body mass index (BMI), muscle weigh (LBW)، Metabolic Rate (RMR) During rest) and use the researcher descriptive approach method to one group using the prior and Post-test The results showed that the Detraining of 10 weeks during the transition period negatively affects in some physical variables (maximum strength, Strength Endurance Explosive Strength Power, flexibility, Agility) as well as measurements of body composition (Weight, body mass index, muscle weigh، Metabolic Rate during rest), while a 10-week detraining did not have a significant effect on muscle weight variability for Mansoura University. The most important are the need for medina physical exercise during training or transition periods, such as swimming and running, in order to protect the health level related with body composition and fitness level.

Keywords: Wrestlers, Detraining, Anthropometric, Body composition, transition period.

\section{Introduction}

Periodization is an organized division of the training in pursuit of basic objectives. (9: 311)

Scientists agreed on the division of the training season into three training periods, , preparation, competition and, transition period. (31: 268) (23:

"Department of training ,Faculty of Physical Education, Mansoura University, Egypt.

Assiut Journal For Sport Science Arts 
304)

(6: 192) (20: 135)

The transition period is the period which links between the end of competitions and the beginning of the new preparation period, where the transition period starts after the end of competitions periods and it ends with the beginning in the new preparation period and this period aims to remove each of physical and mental stress and disposal from results of overtraining through the competition period and rehabilitation of the body to absorb the following training doses and it is the an active rest after the competition season which recoveries the healing and that is through participation in various activities on the practice activities which help in keeping on the level of physical preparation for the player and comfort of the nervous system and breaking the boredom of the continuous training throughout the year. (11: 83) (4: 571)

The loss of fitness player in the transition period makes it difficult to come back to one more time in a short time and it will be a reason in an inability of the player to start a new training course by high level, so the transition period is the most appropriate periods to analyses the previous program and complete the next annual training plan and through this analyzing and positive criticism; both of the player and the coach can avoid the mistakes that they have made so as not to be repeated in the future. $(8: 294,297)$

Some see that the transitional period is a complete rest without doing any physical activity, and some sees that it does extended physical activity and some others see it canceled and transition directly to the training with the same quality of training preparation period. (12: 355) (6: 193)

If the player does not benefit from the transition period, he presents himself in the future because of overtraining into the risks of stress and feeling of boredom of that sport and if the player is detraining in this period, he loses the strength through one week or two weeks and this losing of strength if it continues, it will reflect 
negatively on performance and if he does not detrain month, he starts in losing what he gains from aerobic and aerobic endurance which leads to a drop into the level and losing those elements in the transition period makes it difficult to come back one more time in a short time and it will be a reason in an inability of the player to start a new training course by high level. (15: 259)

The detraining whether total or partial interruption, it leads to the losing an anatomical and physiological adaptations associated with sports performance, the longer the period of detraining, the greater the quality of losing physiological and physical adaptations and its quantity. (26: 298) (15: 35) (19: 132)

Through the researcher field and applied experiences with national team of wrestling coaches; he has observed that the transition period does not get enough attention from the players and the most trainers completely neglected the transition period and give their players full rest in which they do not perform any sports activity for a period of between $8-12$ weeks, this matter which has led to the losing the wrestlers what they acquired from physical abilities such as (power - endurance flexibility - fitness) which affect negatively on body component (fat ratio), (body mass index), (muscle weight), and (resting metabolic rate)and as well the technical level for wrestlers, which called the researcher for identifying the problem of the search as in being a scientific trying oriented to know what happens to wrestlers from physical changes and body component after stopping the training process whether because of injury or due to surgery or because of giving them the negative rest during the transition period to the seasonal training, that matter which is completely contracted with the principles of sports training through continuity and organization.

\section{The aim of the study:}

The study aims to identify the effect of detraining on:

Some physical variables (the strength with its sorts endurance - flexibility agility) for the wrestlers of Mansoura University team.

Some variables of body composition (weight - fat ratio - body mass index - muscle weight - and resting metabolic 
rate) for the wrestlers of Mansoura University team.

\section{Hypothesis}

1- There are statistical significant differences between pre and post test in physical variables when detraining during transition period for Mansoura University varsity team of wrestling for the per test

2- There are statistical significant differences between pre and post test in body composition when detraining during transition period for Mansoura University varsity team of wrestling for the per test.

\section{The study terms:}

1- Detraining: The change which occurs in the adaptations of the body of physical and physiological that leads to shortage for the sports achievement and decline in performance. (19: 168)

2- Body Mass Index: It is one of the measurements that used to measure obesity in individuals and that person is considered where a person is obese if the body mass index has more than $27 \mathrm{~kg} / \mathrm{m} 2$. (2: 33)

3- Resting Metabolic Rate: The quantity of power which used by the individual during the rest due to the body system is doing with the different functions where this ratio ranges from between $60 \%$ to $70 \%$ from energy consumed daily by people who are not practicing sports activities. (32: 174) $(3: 32)(13: 4)$

4- Transition Period: It is the limited time period between the end of the period of competitions directly and the start of the preparation period.(6: 193)

\section{Method of reserch:}

Using the descriptive method with the survey method for one group by using pre and post test because it is suitable for the aim of the study.

\section{The Sample:}

the sample was selected using the deliberate method from the wrestlers of Mansoura university team and their numbers is 18 wrestlers for different weight groups which their ages range from 17 to 21 years after the end of the seasonal training for the studying year 2014 - 2015 and that because of summer holiday and as well, 10 wrestlers were selected for exploratory studies from Mansoura Sporting Club and from the original society of research and from the outside basic sample. 
Table (1)

shows the sample size and its rate for the original society:

\begin{tabular}{c|c|c|c}
\hline \hline No. & The Statement & Number & Percentage \\
\hline \hline 1 & Wrestlers of the exploration study & 10 & $35,71 \%$ \\
\hline 2 & Wrestlers of the basic study & 18 & $64,29 \%$ \\
\hline \multicolumn{2}{c|}{ Total Community } & 28 & $100 \%$ \\
\hline \hline
\end{tabular}

The researcher then age) to make sure that the calculate the coefficient of distribution of the study sample torsion for the variables (age, as shown in Table. height, weight, and training

\section{Table (2)}

The equitable distribution of the study sample in the measurement of the basic variables: (age, height, weight, and training age) $\mathrm{N}=28$

\begin{tabular}{c|c|c|c|c|c|c|c}
\hline \hline The sample & Variables & $\begin{array}{c}\text { Measuring } \\
\text { Unit }\end{array}$ & $\begin{array}{c}\text { arithmetic } \\
\text { average }\end{array}$ & $\begin{array}{c}\text { standard } \\
\text { deviation }\end{array}$ & Mediator & Flattening & $\begin{array}{c}\text { Torsion } \\
\text { coefficient }\end{array}$ \\
\hline \hline \multirow{2}{*}{$\begin{array}{c}\text { The Study } \\
\text { Sample } \\
\text { (Experimental } \\
\text { and }\end{array}$} & Age & Year & 20,03 & 1,170 & 20,00 & $0,395-$ & 0,076 \\
\cline { 2 - 8 } & Height & CM & 173,10 & 2,377 & 173,00 & $1,260-$ & $0,279-$ \\
\cline { 2 - 8 } Exploratory) & Age training & YG & 74,60 & 3,467 & 74,00 & 0,145 & 0,277 \\
\hline \hline
\end{tabular}

It is clear from Table

(2) that all the torsion coefficients of the research samples were ranged between $(0,279-, 0,328)$ and that these values were limited to +3 , indicating the homogeneity of the sample 
Table (3)

The equitable distribution of the sample study in variables measurement under consideration: $N=18$

\begin{tabular}{|c|c|c|c|c|c|c|c|c|}
\hline No. & \multicolumn{2}{|c|}{ The Name Test } & Measuring & Average & Deviation & Mediator & Flattening & Torsion \\
\hline 1 & \multirow{3}{*}{$\begin{array}{c}\text { Maximum } \\
\text { strength }\end{array}$} & $\begin{array}{c}\text { The } \\
\text { strength of } \\
\text { the fist of } \\
\text { the } \\
\text { favorite } \\
\text { hand }\end{array}$ & Kg & 41,55 & 2,812 & 42,00 & $-1,279$ & $0,021-$ \\
\hline 2 & & $\begin{array}{l}\text { Physical } \\
\text { muscle } \\
\text { strength of } \\
\text { the two } \\
\text { legs } \\
\end{array}$ & Kg & 156,27 & 4,416 & 155,500 & 0,932- & 0,515 \\
\hline 3 & & $\begin{array}{c}\text { Muscle } \\
\text { strength of } \\
\text { the back }\end{array}$ & kg & 134,05 & 3,333 & 134,00 & 2,214 & 1,242 \\
\hline 4 & \multirow{3}{*}{$\begin{array}{c}\text { Strength } \\
\text { endurance }\end{array}$} & $\begin{array}{c}\text { The } \\
\text { landing of } \\
\text { slant to the } \\
\text { bend of } \\
\text { arms } 1 / k\end{array}$ & Repetition & 38,33 & 2,722 & 38,00 & $0,895-$ & $0,199-$ \\
\hline 5 & & $\begin{array}{l}\text { Sit down } \\
\text { from } \\
\text { bowing 1/k }\end{array}$ & Repetition & 43,33 & 2,400 & 43,500 & $0,328-$ & $0,673-$ \\
\hline 6 & & $\begin{array}{c}\text { The } \\
\text { landing of } \\
\text { slant from } \\
\text { standing } \\
\text { up 1/k }\end{array}$ & Repetition & 19,58 & 1,502 & 19,00 & 0,090 & 0,810 \\
\hline 7 & \multirow{3}{*}{ Power } & $\begin{array}{c}\text { The } \\
\text { vertical } \\
\text { jump } \\
\end{array}$ & $\mathbf{C M}$ & 39,88 & 2,494 & 39,500 & $0,377-$ & $\mathbf{0 , 5 0 0}$ \\
\hline 8 & & $\begin{array}{c}\text { The broad } \\
\text { jump }\end{array}$ & M & 2,67 & 0,105 & 2,68 & 0,403 & $0,712-$ \\
\hline 9 & & $\begin{array}{c}\text { Push a } \\
\text { medicine } \\
\text { ball to the } \\
\text { maximum } \\
\text { extent }\end{array}$ & M & 5,99 & 0,781 & 5,83 & $0,160-$ & $\mathbf{0 , 3 0 8}$ \\
\hline
\end{tabular}

Assiut Journal For Sport Science Arts 
Follow Table (3)

The equitable distribution of the sample study in variables measurement under consideration: $N=18$

\begin{tabular}{|c|c|c|c|c|c|c|c|c|}
\hline No. & \multicolumn{2}{|c|}{ The Name Test } & Measuring & Average & Deviation & Mediator & Flattening & Torsion \\
\hline 10 & & The bridge & $\mathbf{S}$ & 6,27 & 0,751 & 6,00 & 0,365 & 0,406 \\
\hline 11 & \multirow[b]{2}{*}{ Flexibility } & $\begin{array}{c}\text { Horizontal } \\
\text { distance } \\
\text { for the } \\
\text { bridge }\end{array}$ & $\mathbf{C M}$ & 56,05 & 2,796 & 55,500 & 0,166 & 0,680 \\
\hline 12 & & $\begin{array}{c}\text { The } \\
\text { vertical } \\
\text { distance } \\
\text { for the } \\
\text { bridge }\end{array}$ & CM & 62,83 & 2,225 & 63,00 & $0,908-$ & $0,356-$ \\
\hline 13 & Agility & $\begin{array}{l}\text { Prone } \\
\text { from } \\
\text { standing } \\
\text { position } \\
\text { and crawl } \\
\text { around a } \\
\text { circle }\end{array}$ & $\mathbf{S}$ & 11,94 & 1,349 & 12,00 & $0,998-$ & 0,112 \\
\hline \multicolumn{5}{|c|}{$\begin{array}{l}\text { It is clear from Table } \\
\text { (3) that all the torsion } \\
\text { coefficients of the research } \\
\text { samples were ranged between } \\
(1,242,0,279-) \text { and that these } \\
\text { values were limited to }+3 \text {; the }\end{array}$} & \multicolumn{4}{|c|}{$\begin{array}{l}\text { matter that shares to the } \\
\text { equitable distribution of the } \\
\text { sample in physical variables, } \\
\text { indicating the homogeneity of } \\
\text { the sample. }\end{array}$} \\
\hline
\end{tabular}

Table (4)

The equitable distribution of the sample study in body component measurements under consideration: $\mathrm{N}=18$

\begin{tabular}{c|c|c|c|c|c|c|c}
\hline \hline No & $\begin{array}{c}\text { Body } \\
\text { Composition } \\
\text { Measurement } \\
\mathbf{s}\end{array}$ & $\begin{array}{c}\text { Measu } \\
\text { ring } \\
\text { Unit }\end{array}$ & $\begin{array}{c}\text { arithmeti } \\
\mathbf{c} \\
\text { average }\end{array}$ & $\begin{array}{c}\text { standard } \\
\text { deviation }\end{array}$ & $\begin{array}{c}\text { Mediato } \\
\mathbf{r}\end{array}$ & Flattening & $\begin{array}{c}\text { Torsion } \\
\text { coefficient }\end{array}$ \\
\hline \hline 1 & Weight & $\mathrm{Kg}$ & 73,33 & 2,520 & 74,00 & 0,683 & $0,796-$ \\
\hline 2 & Body Mass Index & $\mathrm{Kg} / \mathrm{m}^{2}$ & 22,55 & 1,503 & 23,00 & 0,606 & $0,178-$ \\
\hline 3 & Fat Ratio & $\%$ & 7,22 & 0,732 & 7,00 & 0,906 & $0,483-$ \\
\hline 4 & Muscle Weight & $\mathrm{Kg}$ & 66,83 & 3,568 & 66,00 & 0,407 & 0,678 \\
\hline 5 & $\begin{array}{c}\text { Resting } \\
\text { Metabolic Rate }\end{array}$ & $\begin{array}{c}\text { Calorie / } \\
\text { daily }\end{array}$ & 1804,27 & 26,532 & 1800,00 & 0,378 & $0,188-$ \\
\hline \hline
\end{tabular}


It is clear from Table

(4) that all the torsion coefficients of the research samples were ranged between $\left(0,678,0,796^{-}\right)$and that these values were limited to +3 ; the matter that shares to the equitable distribution of the sample in body component measurements, indicating the homogeneity of the sample.

Fourthly: Data Collection Tools

1. Devices and tools that used:

Restmeter device to measure the length by Centimeter - Medical Balance - Manometer to measure the strength of the grip by $\mathrm{Kg}-$ Dynamometer to measure the strength of the back and the legs by $\mathrm{Kg}$.

(Stopwatch - Medical balls of weight $3 \mathrm{Kg}$ - Tape measure Wrestling Mat.

2. Physical tests that used in the research:

\section{* Maximum Strength:}

- The strength of grip for hands the manometer was used measuring unit $\mathrm{Kg}$

- Muscle strength for legs the dynamometer was used measuring unit $\mathrm{Kg}$

- Muscle strength for the back the dynamometer was used measuring unit $\mathrm{Kg}$ (5: 294251)

\section{* Strength Endurance:}

- The landing of slant to the bend of arms for a one minute of measuring unit of repetition (22: 143)

- Sit down from bowing for one minute of measuring unit of repetition (22: 139)

- The landing of slant from standing up for one minute of measuring unit of repetition (29: 143)

* Explosive Strength Power

- The vertical jump of Sargent of measuring unit CM (5: 84)

- Standing broad jump of stability of measuring unit Meter (22: 93)

- The test of pushing the medicine ball $3 \mathrm{Kg}$ to maximum range of measuring unit Meter (22: 110)

- Perform the skill of the bridge three times as fast as possible of measuring unit Second (25: 87)

\section{* Flexibility}

- Horizontal distance for the bridge of measuring unit $\mathrm{CM}$ -The vertical distance for the bridge of measuring unit $\mathrm{CM}$ (25:88)

\section{*Agility}

Prone from standing position and crawl around a circle 
of measuring unit Second (21:47)

Body Composition Analysis:

- Variable measurements of body components (weight body mass index - fat ratio muscle weight - resting metabolic rate).

\section{Procedures :}

\section{1-The Pre test}

The Pre test for physical tests were applied from 1/6/2015 to 2/6/2015, and pre measurements of the body composition were applied on 3/6/2015.

\section{2- The Post test}

The Post test were applied after 10 weeks of detraining during the transitional period

\section{Table (5)}

Indication of differences between pre and post measurements in tests of physical variables of experimental groups $\quad \mathrm{N}=18$

\begin{tabular}{|c|c|c|c|c|c|c|c|c|c|c|}
\hline \multirow[t]{2}{*}{$\begin{array}{l}\mathbf{N} \\
\text { o. }\end{array}$} & \multirow{2}{*}{\multicolumn{2}{|c|}{$\begin{array}{c}\text { The Name } \\
\text { Test }\end{array}$}} & \multirow{2}{*}{$\begin{array}{l}\text { leasur: } \\
\text { g unit }\end{array}$} & \multicolumn{2}{|c|}{$\begin{array}{c}\text { Pre } \\
\text { measurem } \\
\text { ent }\end{array}$} & \multicolumn{2}{|c|}{$\begin{array}{c}\text { Post } \\
\text { measurreme }\end{array}$} & \multirow{2}{*}{$\begin{array}{c}\text { The } \\
\text { difference } \\
\text { between } \\
\text { the two } \\
\text { averages } \\
\end{array}$} & \multirow[t]{2}{*}{$\begin{array}{c}\text { T- } \\
\text { tes } \\
\mathbf{t}\end{array}$} & \multirow[t]{2}{*}{$\begin{array}{l}\text { Dr } \\
\text { op } \\
\text { rati } \\
\text { o\% }\end{array}$} \\
\hline & & & & $\begin{array}{c}\text { Medi } \\
\text { ator } \\
\text { S - }\end{array}$ & $\begin{array}{l}\text { Dev } \\
\text { iati } \\
\text { on } \\
+ \text { P } \\
\end{array}$ & $\begin{array}{c}\text { Medi } \\
\text { ator } \\
\text { S- }\end{array}$ & $\begin{array}{l}\text { Devia } \\
\text { tion } \\
\pm P\end{array}$ & & & \\
\hline 1 & $\begin{array}{l}\text { Ma } \\
\text { xim } \\
\text { um } \\
\text { stre } \\
\text { ngt } \\
\text { h }\end{array}$ & $\begin{array}{l}\text { The } \\
\text { stren } \\
\text { gth } \\
\text { of } \\
\text { the } \\
\text { fist } \\
\text { of } \\
\text { the } \\
\text { favo } \\
\text { rite } \\
\text { hand }\end{array}$ & $\mathrm{Kg}$ & 41,55 & 2,812 & 35,16 & 1,653 & $6,39-$ & $\begin{array}{l}* 10, \\
841\end{array}$ & $\begin{array}{r}-15,3 \\
7 \%\end{array}$ \\
\hline
\end{tabular}

Assiut Journal For Sport Science Arts and in the same arrangement of pre measurements, from $15 / 8 / 2011$ to $17 / 8 / 2015$ for physical tests. Body composition measurements were applied on 17/8/2015 in laboratory and Training Hall at the Faculty of Physical Education, Mansoura University.

Statistical analysis: The researcher used statistical programs (SPSS $6.01 \&$ Excel 2010) to process data(Average - Standard Deviation Skewness - Pearson - T-Test Paired - T-Test Independent

Results Presentation and discussion 
Follow Table (5)

Indication of differences between pre and post measurements in tests of physical variables of experimental groups $\quad \mathrm{N}=18$

\begin{tabular}{|c|c|c|c|c|c|c|c|c|c|c|c|}
\hline \multirow[t]{2}{*}{$\begin{array}{l}\mathbf{T} \\
\mathbf{0 .}\end{array}$} & \multirow{2}{*}{\multicolumn{2}{|c|}{$\underset{\text { Test }}{\text { The Name }}$}} & \multirow{2}{*}{ leasuri } & \multicolumn{2}{|c|}{$\underset{\substack{\text { Pre } \\
\text { measurem }}}{\underset{c}{\text { meant }}}$} & \multicolumn{2}{|c|}{$\underset{\text { nt }}{\text { Post }}$} & \multicolumn{2}{|c|}{$\begin{array}{c}\text { The } \\
\text { difference } \\
\text { between } \\
\text { the two } \\
\text { averages }\end{array}$} & \multirow[t]{2}{*}{$\underset{\text { tes }}{\text { T- }}$} & \multirow[t]{2}{*}{$\begin{array}{l}\text { Dr } \\
\text { op } \\
\text { rati } \\
\text { o\% }\end{array}$} \\
\hline & & & & $\begin{array}{c}\text { Medi } \\
\text { ator } \\
\text { S - }\end{array}$ & $\begin{array}{c}\text { Dev } \\
\text { iati } \\
\text { on } \\
+\mathbf{P} \\
\end{array}$ & $\begin{array}{l}\text { Medi } \\
\text { ator } \\
\mathbf{S}-\end{array}$ & $\begin{array}{c}\text { Devia } \\
\text { tion } \\
+\mathbf{P}\end{array}$ & & & & \\
\hline 2 & & $\begin{array}{c}\text { Physi } \\
\text { cal } \\
\text { musc } \\
\text { le } \\
\text { stren } \\
\text { gth } \\
\text { of the } \\
\text { legs }\end{array}$ & $\mathrm{Kg}$ & $\begin{array}{c}156,2 \\
7\end{array}$ & 4,416 & 124,66 & 4,158 & \multicolumn{2}{|c|}{$-31,61$} & $\begin{array}{c}* 23 \\
, 11 \\
5\end{array}$ & $\begin{array}{l}-20, \\
22 \%\end{array}$ \\
\hline 3 & & $\begin{array}{c}\text { Musc } \\
\text { le } \\
\text { stren } \\
\text { gth } \\
\text { of } \\
\text { the } \\
\text { back }\end{array}$ & $\mathrm{kg}$ & $\begin{array}{c}134,0 \\
5\end{array}$ & 3,333 & \multicolumn{2}{|c|}{109,38} & $\begin{array}{c}5,82 \\
2\end{array}$ & $-24,67$ & $\begin{array}{l}* 16, \\
498\end{array}$ & $\begin{array}{c}-18,4 \\
0 \%\end{array}$ \\
\hline 4 & \multirow{3}{*}{$\begin{array}{c}\text { stre } \\
\text { ngt } \\
\text { h } \\
\text { En } \\
\text { dur } \\
\text { anc } \\
\text { e }\end{array}$} & $\begin{array}{l}\text { The } \\
\text { landi } \\
\text { ng of } \\
\text { slant } \\
\text { to the } \\
\text { bend } \\
\text { of } \\
\text { arms } \\
1 / \mathrm{k}\end{array}$ & $\begin{array}{l}\text { Repe } \\
\text { tition }\end{array}$ & 38,33 & 2,722 & & 16 & $\begin{array}{c}2,70 \\
6\end{array}$ & $-7,17$ & $\begin{array}{c}* 9,8 \\
96\end{array}$ & $\begin{array}{c}-18,7 \\
0 \%\end{array}$ \\
\hline 5 & & $\begin{array}{c}\text { Sit } \\
\text { down } \\
\text { from } \\
\text { bowi } \\
\text { ng } \\
1 / \mathrm{k}\end{array}$ & $\begin{array}{l}\text { Repe } \\
\text { tition }\end{array}$ & 43,33 & 2,400 & & 11 & $\begin{array}{c}2,58 \\
7\end{array}$ & $-9,22$ & $\begin{array}{l}* 13, \\
580\end{array}$ & $\begin{array}{c}-21,2 \\
7 \%\end{array}$ \\
\hline 6 & & $\begin{array}{l}\text { The } \\
\text { landi } \\
\text { ng of } \\
\text { slant } \\
\text { from } \\
\text { stand } \\
\text { ing } \\
\text { up } \\
1 / \mathrm{k}\end{array}$ & $\begin{array}{l}\text { Repe } \\
\text { tition }\end{array}$ & 19,58 & 1,502 & & 27 & $\begin{array}{c}0,95 \\
8\end{array}$ & $-4,31$ & $\begin{array}{l}* 14, \\
786\end{array}$ & $\begin{array}{c}-22,0 \\
1 \%\end{array}$ \\
\hline 7 & $\begin{array}{l}\text { Ex } \\
\text { plo } \\
\text { Siv } \\
\text { e }\end{array}$ & $\begin{array}{l}\text { The } \\
\text { vertic } \\
\text { al } \\
\text { jump }\end{array}$ & CM & 39,88 & 2,494 & & 55 & $\begin{array}{c}1,61 \\
6\end{array}$ & $-7,33$ & $\begin{array}{l}* 12, \\
460\end{array}$ & $\begin{array}{c}-18,3 \\
8 \%\end{array}$ \\
\hline 8 & $\begin{array}{l}\text { ngt } \\
\text { h } \\
\text { po } \\
\text { wer }\end{array}$ & $\begin{array}{l}\text { The } \\
\text { broad } \\
\text { jump }\end{array}$ & M & 2,67 & 0,105 & & 27 & $\begin{array}{c}0,12 \\
3\end{array}$ & $-0,40$ & $\begin{array}{l}* 14, \\
296\end{array}$ & $\begin{array}{c}-14,9 \\
8 \%\end{array}$ \\
\hline
\end{tabular}

Assiut Journal For Sport Science Arts 
Follow Table (5)

Indication of differences between pre and post measurements in tests of physical variables of experimental groups $\quad \mathrm{N}=18$

\begin{tabular}{|c|c|c|c|c|c|c|c|c|c|c|c|}
\hline \multirow[t]{2}{*}{$\begin{array}{l}\mathbf{N} \\
\mathbf{0 .}\end{array}$} & \multirow{2}{*}{\multicolumn{2}{|c|}{$\begin{array}{c}\text { The Name } \\
\text { Test }\end{array}$}} & \multirow{2}{*}{$\begin{array}{l}\text { leasuri } \\
\text { g unit }\end{array}$} & \multicolumn{2}{|c|}{$\underset{\text { ent }}{\text { Pre }}$} & \multicolumn{2}{|c|}{$\underset{\text { nt }}{\text { Post }}$} & \multirow{2}{*}{\multicolumn{2}{|c|}{$\begin{array}{c}\text { The } \\
\text { difference } \\
\text { between } \\
\text { the two } \\
\text { averages }\end{array}$}} & \multirow[t]{2}{*}{$\underset{\text { tes }}{\text { T- }}$} & \multirow[t]{2}{*}{$\begin{array}{l}\text { Dr } \\
\text { op } \\
\text { rati } \\
\text { o\% }\end{array}$} \\
\hline & & & & $\begin{array}{c}\text { Medi } \\
\text { ator } \\
\text { S - }\end{array}$ & $\begin{array}{l}\text { Dev } \\
\text { iati } \\
\text { on } \\
+ \text { P } \\
\end{array}$ & $\begin{array}{c}\text { Medi } \\
\text { ator } \\
\mathrm{S}-\end{array}$ & $\begin{array}{l}\begin{array}{c}\text { Devia } \\
\text { tion } \\
\pm \mathbf{P}\end{array} \\
\end{array}$ & & & & \\
\hline 9 & & $\begin{array}{l}\text { Push } \\
\text { a } \\
\text { medi } \\
\text { cine } \\
\text { ball } \\
\text { to } \\
\text { the } \\
\text { maxi } \\
\text { mum } \\
\text { exte } \\
\text { nt }\end{array}$ & M & 5,99 & $\begin{array}{l}0,7 \\
81\end{array}$ & & 73 & $\begin{array}{c}0 \\
50 \\
1\end{array}$ & $-1,2$ & $\begin{array}{l}* 9 \\
44 \\
44\end{array}$ & $\begin{array}{l}-21 \\
, 03 \\
\%\end{array}$ \\
\hline $\begin{array}{l}1 \\
0\end{array}$ & & $\begin{array}{c}\text { Perf } \\
\text { orm } \\
\text { the } \\
\text { brid } \\
\text { ge } \\
\text { skill }\end{array}$ & $S$ & 6,27 & $\begin{array}{l}0,7 \\
51\end{array}$ & & 94 & $\begin{array}{l}0 \\
80 \\
2\end{array}$ & 1,67 & $\begin{array}{l}* 1 \\
1 \\
90 \\
2\end{array}$ & $\begin{array}{l}26, \\
63 \\
\%\end{array}$ \\
\hline $\begin{array}{l}1 \\
1\end{array}$ & flex & $\begin{array}{l}\text { Hori } \\
\text { zont } \\
\text { al } \\
\text { dista } \\
\text { nce } \\
\text { for } \\
\text { the } \\
\text { brid } \\
\text { ge }\end{array}$ & $\mathrm{CM}$ & 56,0 & $\begin{array}{l}2,7 \\
96\end{array}$ & & ,22 & $\begin{array}{l}1 \\
47 \\
7\end{array}$ & 7,17 & $\begin{array}{l}* 9 \\
76 \\
16\end{array}$ & $\begin{array}{l}12, \\
79 \\
\%\end{array}$ \\
\hline$\frac{1}{2}$ & ity & $\begin{array}{l}\text { The } \\
\text { vertic } \\
\text { al } \\
\text { dista } \\
\text { nce } \\
\text { for } \\
\text { the } \\
\text { bridg } \\
\text { e }\end{array}$ & $\mathrm{CM}$ & 62,8 & 2,2 & & ,16 & $\begin{array}{l}2, \\
06 \\
5\end{array}$ & $-6,6$ & $\begin{array}{l}* 1 \\
0 \\
30 \\
8\end{array}$ & $\begin{array}{l}-10 \\
, 61 \\
\%\end{array}$ \\
\hline $\begin{array}{l}1 \\
3\end{array}$ & $\begin{array}{l}\text { Agi } \\
\text { lity }\end{array}$ & $\begin{array}{l}\text { Prone } \\
\text { from } \\
\text { stand } \\
\text { ing } \\
\text { positi } \\
\text { on } \\
\text { and } \\
\text { crawl } \\
\text { aroun } \\
\text { d a } \\
\text { circle }\end{array}$ & $S$ & 11,9 & $\begin{array}{l}1,3 \\
49\end{array}$ & & ,88, & $\begin{array}{l}1 \\
07 \\
8\end{array}$ & 1,94 & $\begin{array}{l}* 9 \\
44 \\
54\end{array}$ & $\begin{array}{l}16, \\
24 \\
\%\end{array}$ \\
\hline
\end{tabular}

"T" tabular value at a significant level 0,05 =1.740

Assiut Journal For Sport Science Arts 
Table (5) shows statically significance differences at the level of significance 0,05 between pre and post measurements for experimental groups for detraining for 10 weeks during the transition period in the special physical tests of wrestlers of Mansoura university team for the sake of the pre measurements as shown by the average of the measurements of experimental groups where the values $(\mathrm{T})$ that calculated for physical tests that were limited between $(9,444: 23,115)$, which is greater than their tabular value. We note the lower arithmetic average in the fixed maximum strength tests of wrestlers in the test of the grip strength of the preferred hand from (41.55) $\mathrm{kg}$ to (35.16) $\mathrm{kg}$, and in the test of strength of the muscle of the two men from $(156,27 \mathrm{~kg}$ to 124.66$) \mathrm{Kg}$, and in the muscle strength test substance for the back of (134.05) kg to (109.38) kg, We note the decrease in the arithmetic mean in the force tolerance tests of wrestlers in the oblivion test for arm flexion for a minute of (38.33) recurrences to test from 1 minute of (43.33) recurrence to (34.11) ), And in the oblique slant test of standing for a minute of (19.58) recurrence to (15.27) recurrence, We also note that the arithmetic mean in the strength tests of the speed of wrestlers in the vertical jump test of Sargent decreased from $39.88 \mathrm{~cm}$ to $32.55 \mathrm{~cm}$ and in the wide jump test from 2.67 to 2.27. Meter), in the test of pushing the medical ball $3 \mathrm{~kg}$ for the maximum range from (5.99) meters to (4.73) meters, and the high arithmetic mean in the test of the performance of the skill of the bridge three times at full speed from (6.27) seconds to (7.94) Second, we also note the height of the arithmetic average in the elasticity measurements of the wrestlers in measuring the horizontal distance of the bridge from $56,05 \mathrm{~cm}$ to 63.22 $\mathrm{cm}$ and the arithmetic mean of the vertical distance of the bridge from $62.83 \mathrm{~cm}$ to 56,16 $\mathrm{cm}$. Also, we note the height of the arithmetic mean in the agility test in the wrestlers in the test of standing up and crawling around the circle (11.94) seconds to (13.88) seconds.

recurrences, and in the sitting 
The results of this study are consistent with the study of Nima et al. 2014 (27). The results of this study showed a decrease in the anaerobic endurance of the wrestlers due to the detraining for 3 weeks, as well as the study of Imad Saleh Abdul Haq 2004 (13); the study showed that the detraining for 8 weeks negatively affected the following physical variables (speed and strength of the muscles of the two men), as demonstrated by the results of the Sergej 2003 (29) that there is an inverse relationship between the proportion of fat and time $(50 \mathrm{~m})$ enemy where the higher the proportion of fat increased The time of the enemy as a result of detraining, and the results of the study of Tarek Mustafa Moumni 2003 (30) that the detraining for 4 weeks was related to reduced aerobic endurance, decreased enemy time and flexibility. The results of the Fleck 1994 study (14) showed that the detraining for 15 days affected the physical variables negatively, especially the endurance and muscle strength. The greater the duration of the detraining, the higher the decrease and vice versa.

The results of the study also differ from the results of the studies by Hustler et al. 2002 (16) that the discontinuation of the two-week training showed no effect on endurance, and the results of Robly et al. 2001 (28) that the detraining for 25 days did not occur of significant effect on loss of elasticity, and the researcher found that the period of discontinuation of training was not enough to cause the effect. Table (5) shows that there is a decrease between the pre and post measurements of the experimental group for the detraining during the transition period for 10 -week in the physical tests of the wrestlers of Mansoura University team for pre measurements as shown by the average measurements. Firmness (strength of the fist of the favorite hand $-15.37 \%$, muscle strength of the material for two men $-20 ' 22 \%$, muscle strength of the material for back -18.40\%), Where the lower ratios of the maximum fixed strength tests have 
skipped (the strength of the fist of the preferred hand $-15.37 \%$, the muscle strength of the material for the two men $20 ' 22 \%$, the muscle strength of the material for the back $18.40 \%$ ), The lower rates of force endurance tests have skipped(oblique arm flexion test for $18-70 \%$ min, sitting test of immobility for 1 minute $21.27 \%$, oblique slant test for stand-up $-22,01 \%$, the rates of the special power speed skipped (Vertical jump $18.38 \%$, wide jump of stability $-14.98 \%$, medical ball push test $3 \mathrm{~kg}$ for maximum range $21.03 \%$, performance of the bridge skill three times at full speed $26.63 \%$ ), and the rates of decrease of measurements of flexibility also skipped (the horizontal distance of the bridge was $12.79 \%$, the vertical distance of the bridge $10.61 \%$ ), and the decrease in the agility test (the land of stand-up and crawl around a circle $16.24 \%$ ). The highest decrease was in the fixed strength tests for the sake of (muscle strength test material for the legs, followed by muscle strength material for the back, then the strength of the fist for the preferred hand), and the highest drop was in the force endurance tests in favor of Sit down for a minute, then test the oblique slant and bend the arms for a minute), The highest decrease was in the strength tests of speed (three times the maximum speed of the bridge skill, followed by the push the medical ball $3 \mathrm{~kg}$ for the maximum range followed by the vertical jump and then the wide jump of stability). The highest reduction was in the elasticity measurements, Then the vertical distance of the bridge). From the results of the researcher's findings, we find that the first hypothesis has been achieved and stipulates: There are statistically significant differences between the tribal and non-tribal standards for the detraining during the transition period in the physical variables of the Mansoura University team for pre measurement. 
Table (6)

Indication of differences between pre and post measurements in the measurements of body components of experimental groups $N=18$

\begin{tabular}{|c|c|c|c|c|c|c|c|c|c|}
\hline \multirow[b]{2}{*}{$\begin{array}{c}\text { No } \\
\text {. }\end{array}$} & \multirow[b]{2}{*}{$\begin{array}{l}\text { Body } \\
\text { Compo } \\
\text { sition } \\
\text { Measur } \\
\text { ements }\end{array}$} & \multirow[b]{2}{*}{$\begin{array}{l}\text { Meas } \\
\text { uring } \\
\text { Unit }\end{array}$} & \multicolumn{2}{|c|}{ Pre test } & \multicolumn{2}{|c|}{ Post test } & \multirow{2}{*}{$\begin{array}{c}\text { The } \\
\text { differenc } \\
\text { e } \\
\text { between } \\
\text { the two } \\
\text { averages }\end{array}$} & \multirow[b]{2}{*}{$\mathrm{T}$ test } & \multirow[b]{2}{*}{ Drop ratio\% } \\
\hline & & & $\begin{array}{c}\text { arith } \\
\text { metic } \\
\text { avera } \\
\text { ge } \\
\mathrm{S}-\end{array}$ & $\begin{array}{l}\text { standa } \\
\text { rd } \\
\text { deviat } \\
\text { ion } \\
+\mathrm{P}\end{array}$ & $\begin{array}{l}\text { arith } \\
\text { metic } \\
\text { avera } \\
\text { ge } \\
\mathrm{S}-\end{array}$ & $\begin{array}{c}\text { standar } \\
\mathrm{d} \\
\text { deviatio } \\
\mathrm{n} \\
+\mathrm{P}\end{array}$ & & & \\
\hline 1 & Weight & $\mathrm{Kg}$ & 73,33 & 2,520 & 74,88 & 1,936 & 1,55 & $* 7,714$ & $2,11 \%$ \\
\hline 2 & $\begin{array}{l}\text { Body } \\
\text { Mass } \\
\text { Index }\end{array}$ & $\begin{array}{l}\mathrm{Kg} / \\
\mathrm{m}^{2}\end{array}$ & 22,55 & 1,503 & 23,44 & 1.338 & 0,89 & $* 6,469$ & $3,94 \%$ \\
\hline 3 & Fat Ratio & $\%$ & 7,22 & 0,732 & 8,27 & 0,751 & 1,05 & $* 19,00$ & $14,54 \%$ \\
\hline 4 & $\begin{array}{l}\text { Muscle } \\
\text { Weight }\end{array}$ & $\mathrm{Kg}$ & 66,83 & 3,568 & 66,77 & 3,490 & $-0,06$ & $* 1,010$ & $-0,08 \%$ \\
\hline 5 & $\begin{array}{c}\text { Resting } \\
\text { Metaboli } \\
\text { c Rate }\end{array}$ & $\begin{array}{c}\text { Calor } \\
\text { ie / } \\
\text { daily } \\
\end{array}$ & 1804,27 & 26,532 & 1734,50 & 16,730 & $-69,77$ & $\begin{array}{c}* 11,56 \\
6\end{array}$ & $-3,86 \%$ \\
\hline
\end{tabular}

Table (6) shows statistically significant differences at the mean 0.05 level between the pre and post measurements of the experimental group for the detraining during the 10 -week transitional period in measurements of body components (weight, BMI, fat ratio, and resting metabolic rate) for the sake of the pre measurements as shown from the average of the measurements for the experimental groups where the value of $(\mathrm{T})$ which calculated for the measurements of the body restricted between $(19,00$
$: 6,469)$ and it is larger than its tabular value, and as well shown statistically significant differences between the pre and post measurements where the value of $(\mathrm{T})$ that calculated has reached $(10,010)$ and it is lower than its tabular value, as we noted increasing arithmetic average for the weight for the wrestlers from $(73,33) \mathrm{Kg}$ to $(74,88) \mathrm{Kg}$, the arithmetic average has higher to body mass index from $(22,55)$ $\mathrm{Kg} / \mathrm{m} 2$ to $(23,44) \mathrm{Kg} / \mathrm{m} 2$, and the arithmetic average to the fat ratio has increased from $(7,22 \%)$ 6o $(8,27 \%)$ and also the arithmetic average of the Assiut Journal For Sport Science Arts 
resting metabolic rate has decreased where it reached from $(1804,27)$ calorie in a day to $(1734,50)$ calorie in a day.

The results of this study are consistent with the study of Emad Saleh Abdul Haq 2004 (13). The results of this study showed that detraining for 8 weeks affects body composition variables (weight - BMI - resting metabolic resting - fat ratio), while agreeing The current study with the study of Tariq Mustafa Momani 2003 (30) in the impact of the detraining for 8 weeks on the variable body weight in the body as it did not give significant differences between the tribal and remote measurements, as shown by the results of the study of Armellini et al. 2000 (7), and the study of Abdul Nasser Alqadoumi 2003 (3) an increase in weight and proportion of fat during the resting after detraining for a particular time period, as for the body composition variable and fat ratio, the current study agreed with the study of Sergej 2003 (29), which aimed to identify the seasonal changes in body composition and the speed of performance of the players, the study found an inverse relation between fat and detraining.

While the current study did not agree with the study of Tarek Mustafa Momani 2003 (30) in the impact of the detraining for 8 weeks on the variable body weight as it did not give significant differences between the pre and post measurements.

As shown in Table (6), there is a decrease between the pre measurements and the post measurements of the experimental group for the detraining during transition period for two months in the measurements of the body components of the Mansoura University team for the pre measurements as shown by the average measurements. Weight $(2,11 \%)$, BMI $(3.94 \%)$, fat ratio $(14.54 \%)$, muscle weight $(-0.08 \%)$, metabolic rate (RMR) (-3.86\%), the highest decrease was in favor of the variable fat ratio $(14.54 \%)$, the lowest percentage of the weight loss was $(-0.08 \%)$, The second hypothesis has been achieved and provides for: There are statistically significant differences between the pre and post measurements for the detraining during the transition period in the body 
composition variables for the Mansoura University team in favor of pre measurement.

Conclusions:

In the light of the aim of the study and its hypotheses and within the limits of the research sample and its characteristics and the methodology, statistical analysis used the researcher has reached to following conclusions:

1. The detraining affected for 10-week during the transition period negatively in some physical variables such as the tests of (maximum strength, strength, endurance power, flexibility, agility) for the wrestlers of Mansoura university varsity team.

2. The detraining affected for 10 -week during the transition period negatively in the measurements of the body composition composition (weight - fat ratio - body mass index - muscle weight resting metabolic rate) for the wrestlers of Mansoura university varsity team.

3. The detraining for 10 -week did not have a significant effect on the muscle weight variable. Recommendations:

In light of the aim of the study and the presentation of its results and discussion, the researcher recommends that:

1. It's necessary for performing of physical exercises moderate intensity during the detraining or in the transition period such as swimming and running, in order to maintain the side health which links with the body composition and fitness level.

2. It's necessary to conduct a study on the effect of detraining of blood biochemistry for the wrestlers and individual sports.

3. It's necessary to conduct comparative studies between practitioners and nonpractitioners during detraining period to identify the differences between them.

\section{References:}

1. Abdul Aziz El Nemr, Nariman Muhammad Al Khatib: Sports training weight training, design of force programs and training season planning, book center for publishing, Cairo, 2005.

\section{Abdul Nasser Al}

Qaddoumi, Sobhy Nimr:

Build standard levels of body mass index, fat ratio, muscle 
weight, body surface area, and resting metabolic rate for female students in physical education. Journal of An Najah National University, Vol. (19) number (4), 2005.

\section{Abdul Nasser Al-}

Qadumi: Body mass index and resting metabolic rate for the football player that were participated in the 20th Arab Men's Volley ball Championship in Jordan, Al- Najah for researchers - Human Sciences Series, El- Majd (B) (17), Number (1), page (31 - 57), 2003.

4. Abou El Ela Ahmed Abdel Fattah, Raysan Kharabyet: Sports training the book center publisher, Cairo 2016.

\section{Ahmed Muhammad} Khater, Ali Fahmy Al Beek: The measurement in the sports Field, Dar Al Ma'arif, 4, Cairo, 1996.

6. Ali Said Rehan: The impact of a proposed training program for the transition period on some health-related fitness components for adult wrestlers, Scientific Journal of Physical and sport Sciences, No. 1, pp. 191-233, Faculty of
Physical Education, Mansoura University, 2003

7. Armellini, F, Zamboni M, Mine A \& et.al: ood in relation to body composition and adipose tissue distribution, Metabolism, (44), (1). Pp. 610, 2000.

8. Awyes Ali El-gabli: Sport Training Theory and Practice, I 2, G.M.S, Cairo, 2004.

9. Dick,w.f : Sports Training Principles. $5^{\text {th }}$ ed A\&CBlack (publishers)., London, 2007

10. Dick Frank.: Sports Training Principles, London, 1980.

\section{Dietrich}

Harre:

Principles of Sports Training Sport Verlao, 3rd Edition, 2001.

12. El-Sayed Abdel

Maqsoud: Theories of Sports Training - Training and Physiology of Power, First Edition, The Book Center for Publishing, Cairo, 1997.

\section{Emad Saleh Abdul Haq:}

The effect of detraining on some physical variable and body composition for the player of the successful national football team, Department of Physical 
Education, An - Najah National University, 2004.

\section{Fleck S. J.: Detraining:}

its effect on endurance strength. Strength Condi. Sport Science Technology Division U.S. Olympic Committee, 1994.

\section{Fontoura AS, Schneider}

P, Meyer: Effect of the muscular strength detraining in prepubertal boys. Rev Bras Med Esporte, 2004.

16. Hostler, David Paul: The effect of high intensity cycle training muscle structure and gene expression. Ohio University, 20002.

17. Kraemer WJ, Koziris LP, Ratamess NA, Häkkinen K, \& et.al: Detraining produces minimal changes in physical performance and hormonal variables in recreationally strength-trained men. The Journal of Strength \& Conditioning Research. 16(373 : 382), 2002.

18. Laforgia J, Withers RT, Williams AD, Murch BJ, \& et.al: Effect of 3 weeks of detraining on the resting metabolic rate and body composition of trained males.
European Journal of Clinical Nutrition. 53: 126-134, 1999.

19. Lee I, Rohaan N,: Detraining effect of the postseason on selected aerobic and anaerobic performance variables in national league rugby union players: a focus on positional status. Sports Med. 4: 161-168, 2010.

20. Mosaad Ali Mahmoud: Encyclopedia of Roman wrestling and free for amateurs (education - training management - arbitration), book National house, Mansoura, 2003.

\section{Mosaad Ali Mahmoud:}

The construction the skill test for the agility for the wrestlers, Theories and Approaches Magazine, second edition No. 2 (18), faculty of physical education for men, Alexandria University, 1994

22. Muhammad Hassan Allawi, Muhammad Nasr El Din Radwan: Performance tests, Daralfikr Al Arabi, Cairo, 2001.

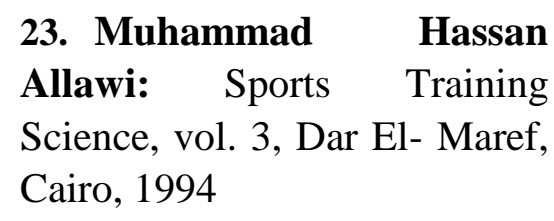


24. Muhammad Nasr El Din Radwan: Reference in physical measurements, I 1, Dar al-Fikr al-Arabi, Cairo, 1997

25. Muhammad Reda Al Roubi: The principles of training in wrestling sport. The artistic performance of the movements in Greek - Roman wrestling, first edition, Mahi for computer services, Alexandria, 2005.

26. Mujika I, Padilla S,: Muscular characteristics of detraining in humans. Medicine \& Science in Sports \& Exercise. 33(8): 1297-1303, 2000.

\section{Nima Gharahdaghi,} Yaqoub Mehri Alvar, \&et al: The Effects of A Short-Term Detraining on Anthropometric, Hormonal and Functional Factors in Male Wrestlers, Journal of Research in Applied sciences. Vol., 1(3): 63-69, 2014

\section{Rubly, M. Brucker, J.} Knight, K. Ricard,: Flexibility retention 3 weeks after a 5-day training. J Sport Rehabil, 2001

29. Sergei, M. O.: Seasonal alteractions in body Assiut Journal For Sport Science Arts composition and sprint performance of elite soccee players, an international electronic journal, V.G., N.3.,2003.

30. Tariq Mustafa AlMomani: Effect of detraining on Some Physiological and Physical Variables, Unpublished Master Thesis, Yarmouk University, Jordan, 2003.

\section{Tudor O. Bompa:}

Periodization training for sports, High-Performance Sport Conditioning, Bill Foran Editor, Human Kinetics Pub ., Inc U.S.A, 2001.

\section{2- Wilmore JH, Costill DL:} Physiology of sports and exercise Champaign, ILL: Human Kinetics, 1994. 